\title{
Vasné Tóth Kornélia, Múltunk neves ex libris gyüjtői, Lexikon, Budapest, Kisgrafika Barátok Köre Grafikagyüjtő és Müvelődési Egyesület, 2019. 256 p.
}

Többarcú, sokszorosított, esetleg kis példányszámú, individuális nyomtatvány az ex libris. Történetét tekintve funkcionális értéke inspirálta létrejöttét: könyvek, könyvgyüjtemények darabjait és tulajdonosukat, tulajdonosaikat rendelte egybe. Szöveges, a birtokosra vonatkozó bejegyzések már kódexekben, ősnyomtatványokban is találhatók, amelyek a tulajdonos által élvezett szellemiek mellett az anyagiakat is egyértelmüsítették. Később a használati érték megmaradása mellett - párhuzamosan avval, hogy könyvtárat, könyvgyüjteményt, föleg a könyvnyomtatás elterjedése után polgári származásúak, értelmiségiek is felépíthettek maguknak -, rajzukban az addig egyeduralkodó címerábrázolások háttérbe szorultak, s helyükbe különféle kisgrafikai alkotások kerültek, amelyek vizualitása, motívumbeli változatossága a könyvjegyeket a művészetek felé vitte. A modern ex librisek általában intézményi, családi, illetve személyes tulajdont jelölhetnek. Ezeken a tulajdonosi névmegjelölés mellett tért kap(hat)nak egyéb szöveges üzenetek is, amelyek részben a könyvbaráttal, részben az ábrázolt rajzzal állnak kapcsolatban, s evvel megjelenik a mủvelődéstörténeti szempont is. A múlt század elejétől pedig hozzájárult mindehhez a használati funkció lazulása, az ex librisek elváltak a könyvektöl s önálló gyüjteményekben saját életet kezdtek; a kollekciók egyenértéküvé váltak a könyvekkel, amelyekbe belekerültek (volna) - sok esetben el is különültek azoktól. Evvel párhuzamosan kialakult a gyüjtésükkel kapcsolatos egyesületi élet, valamint a feltáró-értékelő szakirodalom.

A szerző több korábbi, a vonatkozó szakirodalmat gazdagító munkája után - csak említésképpen megnevezve az Ex libris és képkultúra címü, 2016-ban megjelent, az albumok és az ismertetések erényeit ötvöző kötetét - most egy életrajzi lexikont állított össze a legismertebb, 1920. századi gyűjtőkről. Aki belefogott már ilyesmibe, foglalkozott hasonló, kézikönyv igényü kiadvány megírásával, szerkesztésével, tapasztalatból tud(hat)ja, hogy milyen buktatókat rejt többek között például a korábbi munkák helytelen, kiadványról kiadványra öröklődő évszámainak korrigálása, a rendelkezésre álló források adatainak fogalmi és ténybeli szóródása. De ez csak az egyik problémahalmaz, mert a szócikkek igen jelentős része kimondottan ehhez a lexikonhoz készült, s nyilván szembesülni kellett az első gyüjtés nehézségeivel, bizonytalanságaival az életrajzi adatokban - látható, hogy több gyüjtőnek még a pontos születési és halálozási éve sem ismert -, az egykor volt gyüjtemények sorsában - együttmaradásában, felbomlásában -; s mindez nyilván befolyásolta az egyes szócikkek terjedelmét, a számba vett gyűjtők/gyűjtemények földrajzi megoszlását is. Ugyanakkor első olvasás, első böngészés után is megállapítható, hogy a kötet egésze maga is önálló forrásértéket nyer(t), ismeretei, adatai kapcsolódó témakörü, hasonló kiadványok szócikkeibe beépülve, tudományos és népszerüsítő tanulmányok, ismertetések, cikkek hivatkozásaiban, lábjegyzeteiben továbbélve léteznek majd tovább.

A kötetben 220 szócikk olvasható. Középpontjukban - ahogy a szerző céljai közt a bevezetőben is utal erre - az ex libris és gyüjtése áll, minden más életrajzi adat csak evvel kapcsolatban szerepel, egyéb vonatkozásokban nem törekszenek a szócikkek teljességre. Terjedelmük különbözőségének másik oka ebben rejlik: akinek jelentősebb, központibb szerepe volt az egyesületi munkában, gyüjteményének összetétele, története jobban ismert, az természetesen hosszabban szerepel. Amennyiben lehet valami biztosat tudni az egyes gyüjtemények sorsáról tulajdonosaik halála után, a szócikkek azt is tartalmazzák.

A szerzői bevezető többek között ismerteti az ex libris-készítés és -gyüjtés 19. század végi fellendülését, valamint szervezeteit; érdemes talán megjegyezni, hogy ebben az időszakban, az 1880as évektől kezdve lendült fel Európa-szerte a képeslapküldés, valamint -gyüjtés divatja is, ami szintén a vizualitás terjedését és igényét, valamint az ipari sajtó előállító lehetőségét mint másik hajtóerőt erősítette meg. A szócikkek csak lezárt életpályákat tartalmaznak, a gyüjtők közül a legidősebbek az 1840-es években születtek, a legfiatalabb életpálya 1956-ban kezdődött. A 20. század 
elején szép számmal hódoltak ennek a hobbinak - amit az élénkülő egyesületi élet (Szent György Céh) is mutat a századforduló, a szecesszió idején. Hasonló aktivitás figyelhető meg a MEGE (Magyar Exlibrisgyüjtők és Grafikabarátok Egyesülete) megalakulásával az 1930-as évektől, illetve a KBK (Kisgrafika Barátok Köre) 1959-es létrejöttétől. A kötet időhatárának lezárását a 2017-es halálozási év jelzi. A jelen legjelentősebb gyüjtőit - köztük saját magát is - a szerző a bevezetőben említi.

Egy lexikon olvasói stratégiája többféle lehet. Az elejétől a végéig tartó, megszakítatlan olvasás azonban a legkevésbé sem, mert az (valamennyire) a szépirodalmi munkák számára van fenntartva, amelyekben a cselekmény - már ha van - folyamatossága lényeges értési szempont; az ilyen jellegü munkákat inkább valamilyen tényprobléma megoldására vagy információsorozatok megszerzése érdekében, tehát szakadozottan szokták fellapozni.

Böngészés közben talán az egyik meglepő tapasztalat - bár, miért is lenne másképp? - az, milyen tág foglalkozási körben voltak/vannak hívei az ex libris kedvelésének. Az még magától értetődik, hogy - maga a gyüjtés, mint tevékenység - elsősorban értelmiségi körökben népszerü, van is a kötetbe kerültek között irodalom- és müvészetközeli számtalan: író és irodalomtörténész, nyelvész, nyomdász, könyvkereskedő, könyvkötő, könyvtáros, történész, jogász, tanár, mellettük a reáliák művelői: (ember- és állat-)orvosok, mérnökök, akadnak gyógyszerészek, archeobotanikus, növénynemesítő, sportoló/sportújságíró; egyházi emberek: piarista tanár, esperes-plébános. De azt talán nem gondolná a gyanútlan olvasó első pillanatban, hogy tsz-elnök, kereskedő, címfestő, katona, könyvelő, rendőrkapitány, a legkülönbözőbb hivatalnokok, fodrász, szállodás, városi főjegyzö, elektromüszerész, vasesztergályos/gépésztechnikus is hódolt ennek a szenvedélynek. A második, részletesebb olvasás már több részletet mutat. Például azt, hogy az egyik szenvedély maga után vonhatja a másikat: az ex libris, a bélyeg, a képeslap, az elsődleges grafika, a numizmatika vagy más kollekciók békésen megférhetnek egy helyen a tulajdonos szándéka szerint. Néha a gyüjtés összefonódik a családi élettel, azaz a kollekciók alakításában nemegyszer a férjek mellett a feleségek is részt vesznek, számukra is készülnek jelzett lapok, esetleg egy gyüjtemény létrehozásában társulva vagy önállóan, férjüknél is nagyobb szerepük lehet. Igen tanulságos végigkövetni a gyüjtemények sorsát létrehozójuk halála után: szétszóródás és továbbőrzés fokozatai között. Itt csak említeni lehet az egymással is szembefeszülő hatalmaknak kitett Weisz Imre, illetve Hillinger Oszkár sorsát, életét; gyüjteményeik különbözö, de végeredményben egyaránt az ismeretlenbe hulló kálváriáját. A recenzenst pedig személyesen is érdekelné, vajon mi lett Szász Sándorné japán metszetgyüjteményének a sorsa.

Rendkívül érdekes, néha váratlan, ami az egyes szócikkekből kiderül: a szellemi élet más és más szegmenseivel foglalkozók közül ki kedvelte ezeket az apró grafikai lapokat is: Balassa József, Bélley Pál, Csaplár Ferenc, Csatkai Endre, Foerk Ernő, Galambos Ferenc, Glück Frigyes, Kner Imre, Lyka Károly, Rozsnyay Kálmán, Semsey Andor, Soó Rezső, Szalay József, Szentkuty Pál, Szíj Rezső, Tompos Ernő, Tüskés Tibor, Varjú Elemér. A felsoroltak mind jelentős szereplői voltak a magyar kultúrának, de hogy emellett még az ex libris is érdekelte őket, az - feltehetően - sokaknak meglepetést fog okozni. S csak annak alátámasztására, hogy minden mindennel összefügg, kell említeni: Dirner Gusztáv Adolf Jászai Mari diákkori pajtása volt - az utóbbi elbeszélésében -; Einczinger Ferenc - többek között - Babits Mihály egyik esztergomi barátja, helyi ügyeinek segítője; Vajda Béláné Kellner Erika pedig Kilényi Irmának, Juhász Gyula szegedi pártfogójának volt a barátnője, sorsával, deportálás utáni visszaérkezése néhány homályos pontjával a Kosztolányi Dezső levelezéséhez kapcsolódó Juhász Gyula-hagyaték hányattatásaival kapcsolatban lehet - érintőlegesen - találkozni. Mindezek persze nincsenek kapcsolatban gyüjteményükkel - utóbbinak, a róla szóló szócikk szerint inkább csak néhány nevére szóló lapja volt -, csak segít a tulajdonosokat elhelyezni saját korukban. 
A szócikkeket illusztrációk, fekete-fehér és többszínnyomású ex librisek követik. Stílusuk a szecesszióval kezdődik, a válogatás mintegy időben meghosszabbított párdarabja Horváth Hilda Magyar ex librisek 1525-1985 címü, csak illusztrációkat tartalmazó kötetének. A válogatott lapok grafikai szempontból ötletesek és kvalitásosak, talán legjobban sikerült Orosz István Soó Rezsőnek készült részkarca, amelyen egy búzakalász szemeit nagyítóval számoló tücsköt lehet látni. A kötetet gazdag - válogatott - irodalomjegyzék zárja.

Bevezetőjében a szerző megjegyzi, a kötetben sokéves kutatási eredményeit teszi közzé. A befektetés nem veszett kárba, hiánypótló munka született.

Buda AtTILA

\section{Eric Suire, Les Vies de Jésus avant Renan, Éditions, réécritures, circulations entre la France et l'Europe (fin XVe-début XIXe siècle), Genève, Droz, 2017 (Cahiers d'Humanisme et Re- naissance, 144.). $316 \mathrm{p}$.}

Jésus élettörténete az egyetemes keresztény müvelődéstörténet egyik meghatározó narratívája, amellyel elsősorban a teológia egyik külön ága, a krisztológia foglalkozik. Eric Suire, az Université Bordeaux-Montaigne professzora legújabb könyvét a kora újkori nyugat-európai - elsősorban francia és latin nyelvü - Jézus életének szentelt nyomtatott és kéziratos munkák jellegzetességeinek és fejlődési változásainak szentelte. A szerző érdekes megközelítésben azokat a könyvnyomtatásban megjelent, illetve részben kéziratban fennmaradt műveket veszi számba, amelyek Jézus Krisztus életét történelmi megközelítésben ábrázolták. A történelmi Jézus életét rekonstruálni kívánó új- és legújabb kori kutatások előtörténetébe vezet ez a munka, amely szigorúan meghatározott módszerek és eszközök segítségével összeállított szövegkorpusz vizsgálata alapján igyekszik válaszolni arra a kérdésre, hogy miért és milyen módon írták folyamatosan újra Jézus élettörténetét a reneszánsz és a francia forradalom közötti időszakban. A szerző alapvetően két fontos könyvtári katalógus alapján állította össze a vizsgált szövegek listáját, vagyis a Catalogue des livres imprimez de la Bibliothèque du Roy és Jacques Lelong Bibliotheca sacra című kézikönyvek és egyéb egyházi könyvtári katalógusok segítségével, amelyek adatait különféle modern könyvtári adatbázisok (BN-Opale plus, CCfr, Sudoc, Gallica, Bayerische StaatsBibliothek digital, Biblioteca Digital Hispánica stb.) segítségével pontosította. Az első 1739-ben kiadott, ma már elég elavultnak tűnő katalógus nagy előnyét abban látta, hogy annak összeállítói eleve külön típusokba osztva jelentették meg az általuk vizsgált könyvek adatait, amely korabeli megfigyelésen alapuló osztályozást a modern elektronikus könyvtári katalógusokban sajnos hiába keresnénk. Eric Suire ezek alapján 190 európai kiadású latin és francia nyelvủ Jézus élettörténetével foglalkozó munkát azonosított a 15. század vége és a 19. század eleje közötti időszakból. Ezek közül 179 volt önálló kiadású munka, és 11 pedig valamilyen nagyobb kiadvány részeként jelent meg. A nyelvi kritériumok alapján a szerző elsősorban a francia nyelvü - eredeti és fordított - müveket, illetve a francia klérusra bizonyíthatóan jelentős hatást gyakorló latin nyelvü munkákat részesítette előnyben. A vizsgálat ezen módszere alapján egy jól átlátható és nyelvileg feldolgozható korpuszt állított össze Suire, viszont a kötet kétségkívül elsősorban a francia olvasók szemszögéből mutatja be a témát. A prózai munkák mellett a szerző figyelembe veszi a verses munkákat is, viszont teljesen megfeledkezik a Krisztus életét bemutató biblikus dramatizált művekről, amelyek bizonyára szintén érdekes adalékokkal gazdagították volna az elemzéseit.

A filológiai alapossággal vizsgált mủvek alkotói sokat merítettek a nagy elődök munkáiból, akiknek neveivel gyakran találkozunk a könyv lapjain: az első ismert evangéliumharmóniák szerzőin (pl. Tatianus) kívül elsősorban karthauzi Szász Ludolf Vita Christije, Andreas Osiander Harmoniae evangelicaeja vagy Jacobus de Voragine Aranylegendája gyakoroltak nagy hatást az utókorra. A vizsgált korszak több szempontból is igen fontos változásokat hozott a Jézus-életrajzok 